\title{
PENGARUH PELAKSANAAN SUPERVISI PENDIDIKAN TERHADAP KINERJA GURU DI SEKOLAH
}

\author{
Fauzza frezzy agusrival 1702013
}

fauzzafrezzy04@gmail.com

\begin{abstract}
ABSTRAK
Perubahan peran guru yang tadinya sebaga penyampai pengetahuan dan pengalihan pengetahuan dan pengalihan keterampilan, serta merupakan satusatunya sumber belajar, berubah peran menjadi pembimbing, pembina, pengajar, dan pelatih. Dalam kegiatan pembelajaran, guru akan bertindak sebagai fasilisator yang bersikap akrab denga penuh tanggung jawab, serta memperlakukan peserta didik sebagai mitra dalam menggali da mengelola informasi menuju tujua belajar mengajar yang telah direncanakan. Guru sebagai pihak yang berkempentingan secara operasional da mental harus dipersiapkan dan ditingkatkan profesionalnya, karena hanya dengan demikian kinerja mereka dapat efektif, apabila kinerja guru efektif, apabila kinerja guru efektif maka tujuan pendidikan akan tercapai. Hasil penelitian ini bertujuan untuk mengetahui pelaksana supervisi pendidikan terhadap kinerja guru disekolah. Data penelitian ini di analisis menggunakan koefesien korelasi sperman. Hasil penelitian ini menunjukan bahwa pelaksanaan supervisi bahwa tidak terlalu berpengaruh terhadap guru.
\end{abstract}

Kata kunci : pelaksanaan, supervisi pendidikan, kinerja guru

\section{LATAR BELAKANG}

Pendidikan nasional berfungsi mengembangkan kemampuan dan membentuk waktak serta peradaban yang bermatabat dalam rangka mencerdaskan kehipan bangsa, bertujuan untuk berkembangnya potensi pesert didik agar menjadi manusia yang beriman dan bertaqwa. Guru adalah aktor utama dalam manajemen pembelajaran pada satuan pendidikan, kurikulum, model pembelajaran, metode, bisa berubah sesuai kebijakan dak kebutuhan yang relevan, namun kunci dari keberhasilan tetap kembali kualitas dan kinerja guru.

Supervisi adalah salah satu upaya yang dilaksanakan kepala sekolah dalam rangka mendorong peningkatan kinerja, kualitas dan kompetensi guru. Supervisi dalam pengertian ini adalah supervisi pendidikan. Dengan adanya pelaksanaan supervisi ini akan berdampak pada kinerja guru dalam pelaksanaan pembelajaran. 


\section{KAJIAN LITERATUR}

Menurut Muljono, 2010 mengatakan bahwa supervisi adalah suatu proses yang merupakan bagian dari proses penididikan, juga sebagai proses sosial yang demokratis, yang fungsi utamanya ialah kepemimpinan. Fungsi supervisi ini adalah memeberi petujuk, mendorong, menjelaskan, memimbing, dan membantu meningkatkan situasi belajar, serta membantu para guru agar ia mengajar lebih baik. Pada dasarnya supervisi dilakukan oleh pihaka yang memiliki kemampuan lebih baik dari pada yang disupervisi karena tujuan supervisi adalah membantu untuk menjadi lebih baik lagi di Masa yang akan datang, selain itu kegiatan supervisi perlu direncanakan dengan baik. Supervisi bukan hanya sarana mencari kesalahan-kesalahan guru dan berhenti pada pelaksanaan supervisi. Melalui supervisi, siswa dan guru memperoleh bantuan untuk meningkatkan mutu yang pada akhirnya menigkatkan mutu pendidikan.

\section{PEMBAHASAN ATAU KAJIAN ANALISIS}

Fungsi supervisi adalah :

a. Merencanakan program supervisi akademik dalam rangka peningkatan profesionalitas guru

b. Melaksanakan supervisi akademik terhadap guru dengan menggunakan pendekatan dan teknik supervisi yang tepat

c. Menindaklanjuti hasil supervisi akademik terhadap guru dalam rangka peningkatan profesionalisme guru.

Ketiga diatas dapat di pahami dan dilaksanakan oleh kepala sekolah dalam merencanakan, melaksanakan, mengevaluasi, dan menindaklanjuti program supervisi untuk perbaikan maupun pengembangan di masa mendatang.

Menurut Rismawan Edi (rismawan, 2015) kemampuan manajemen seorang guru dalam merencanakan, mengorganisasian, melaksanakan, mengontrol, mengevaluasi, dan menindaklanjuti merupakan kemampuan yang sangat menentukan keberhasilan siswa sekaligus keberhasilanya. Dengan kemampuan dan kemauan yang dimiliki maka kinerjanya dapat meningkat denga cepat. Salah satu faktor yang dapat membantu guru dalam meningkatkan kinerjanya adalah supervisi kepala sekolah.

Upaya-upaya yang dapat dilakukan untuk meningkatkan kinerja guru melalui supervisi. Pengaruh supervisi yang dilakukan oleh kepala sekolah dapat meningkatkan kinerja guru jika identifikasi kebutuhan sesuai dengan kebutuhan yang sebenarnya. Hal ini dapat terkait dengan perencanaan dan pelaksanaan supervisi yang di lakukan oleh kepala sekolah. Pendekatan yang di lakukan sebelum, selama, dan setelah supervisi juga mempengaruhi hasil dan tindak lanjut perbaikan maupun pengembangan di masa mendatang.

Upaya untuk meningkatka kinerja guru dapat dilakukan melalui berbagai cara misalnya, pembinaan, penataran, pelatihan ataupun pemberian kesempatan untuk belajar lagi guna meningkatkan kompetensi para guru, perlu di adakan pula 
peningkatan kedesiplinan, pemberian motivasi bahkan pemberian insentif yang layak sehingga memingkinkan guru merasa puas. ( mafidah \& asrori, 2016 ). Sebagaimana menurut Sabandi (Sabandi, 2013) Pendekatan peningkatan keprofesionalan guru tersebut dapat dilakukan dengan teknik supervisi, menumbuhkan budaya organisasi pembelajar, dan kegiatan pelatihan.

Dalam konteks kinerja guru, upaya-upaya meningkatkan kinerja sangat tergantung dari upaya semua elemen sekolah terutama kepala sekolah untuk memberikan informasi, menciptakan hubungan, dan memberikan solusi secara tepat. Beberapa hal yang menyebabkan tujuan supervisi tidak tercapai yaitu kepala sekolah cenderung mencari kesalahan-kesalahan atau kelemahan-kelemahan guru merasa tahu segalanya,melakukan observasi tetapi tidak melakukan tindak lanjut, menggunakan teknik yang monoton, dan kurang pengetahuan.

Tujuan pelaksanaan program supervisi adalah membantu guru dalam meningkatkan kinerja sekaligus mutu pendidikan. Pemahaman dan pemantauan teknik supervisi yang tepat, pengetahuan-pengetahuan yang berkaitan dengan supervisi, kemampuan mengidentifikasi kebutuhan guru, mengenal kepribadian guru, dan faktor-faktor lain yang terkait sangat memperngaruhi keberhasilan supervisi dalam meningkatkan kinerja guru.

\section{KESIMPULAN DAN SARAN}

Upaya-upaya yang dapat dilakukan untuk meningkatkan kinerja guru melalui supervisi. Pengaruh supervisi yang dilakukan oleh kepala sekolah dapat meningkatkan kinerja guru jika identifikasi kebutuhan sesuai dengan kebutuhan yang sebenarnya. Hal ini dapat terkait dengan perencanaan dan pelaksanaan supervisi yang di lakukan oleh kepala sekolah. Pendekatan yang di lakukan sebelum, selama, dan setelah supervisi juga mempengaruhi hasil dan tindak lanjut perbaikan maupun pengembangan di masa mendatang.

Dengan adaya supervisi ini hendaklah dapat berpengaruhi terhadap kinerja guru di sekolah agar meningkatnya kualitas dan pengembangan guru dalam mengajar disekolah. 


\section{REFERENSI}

Sabandi, A. (2013). Supervisi Pendidikan Untuk Pengembangan Profesionalitas Guru Berkelanjutan. Pedagogi, Jurnal Ilmiah Ilmu Pendidikan, XIII(2), 1-9. Retrieved from http://ejournal.unp.ac.id/index.php/pedagogi/article/view/4275 